\title{
History as Ideology
}

\section{Lidiya I. Kirsanova \\ Olga A. Korotina}

Vladivostok State University of Economics and Service

Email: lidiya.kirsanova@vvsu.ru

\section{Doi:10.5901/mjss.2015.v6n3s4p31}

\section{Abstract}

The article considers the question of re-ideologization in modern Russia and in the world. The author understands the ideology as the universal enforcing to joint being. Ideology as a universal refers to the same universals as law, art, science, religion, regulating social discourses according to historical era. The peculiarities of ideology in modern Russia are followings: ideology is the product of a cynical mind where the words do not correspond to reality, the truth of the ideology is impossible - it is pure co-communication without references; The ideology of modern Russia "steals" the story in order to manipulate the community, creates a "historical narrative" of such concepts as a great power, Empire, patriotism and glorification of military history, and so on; in ideology clearly differ suggestion (obsession with idea) and logos as an ideological construct, which is the operator of the emotional sphere of common life. The author notes similar processes of re-ideologization in the Western world - Europe, America. Ideologies have to justify the Foundation of the joint being in the presence of different regions, which is the Western world, Russian world American world and others, today the situation unfolds in a situation of dispute and even strife, when each of the parties comes from a different understanding of justice. There is a contradiction of studies: American atlantism based on the priority of human rights and the European mentality, committed to the Hegelian priority of law. In Russia the law, both domestic and international, guaranteed by the Sovereign is more important than the subjective right of man and citizen. Therefore, there are different ideologies that create conflicts.

Keywords: re-ideologizing, ideology, Mimesis, Logos, modern Russia.

\section{Introduction}

Reasoning about ideology should immediately be premised to a few points, which clearly and unambiguously will indicate the novelty of discourse, because dogmatism and formalism of critique of ideology as a potentially false consciousness, characteristic of the era of confrontation between capitalism and communism do not let to consider ideology as one of the universals of the human community, along with the right, art, science and etc.

1. Thesis: there is no society without ideology means that in it weaker or stronger feels the deficiency that allows the society to be together. As soon as the joint existence is under threat, immediately in a society appears vague feeling that something is wrong, something is not, by itself, i.e., a call to justify the community appears. Ideology is the perfect compulsion to compability of existence.

2. The ideology, the essence of the logos and mimesis. The mimesis as an experience of compability of existence, "being-with" allows a certain obsession (nationalism, patriotism, religiosity, etc.), while the logos is in cold prudence in the choice of some idea - American antlantism, German Fatherland, Moscow - the third Rome, etc.

3. Compability of existence as presence is in need of representation, exposedness from each other in different regions of everything: the West against the East, the Anglo-Saxon imperialism against Eurocentrism and other. Ideology is a mirror of one's social existence to another.

As ideology joins regions of the different things, speech is required, language, text, visuals for addressing and reception of messages. The dialogue between these different regions of the things does not stop even war, on the contrary, when the violence of the addresser and the addressee increase, this leads to the fact that the "flight of meaning" is shortened due to stereotypes, prohibitions on certain types of discourses, minimizing of critic and etc. The chain of signifiers is shortened, which in itself testifies to the intervention ideology. 


\section{Literature Review}

This article uses ideas of Slavoy Zizek from the book "the Sublime object of ideology" in particular establishment of request of the modern world to re-ideologization. Returned subject of ideology is characterized by such properties as cynicism, the tendency to manipulate public consciousness, based on information resources, disregard for reality.

Franklin Ankersmit introduced in the philosophy of history, the concept of the ideal narrative, which proved to be very productive for our study. Historical narrative is assembled from the events of history, which give the existential, moral, ideological value, making it suitable for impact on social subjects. Substantial assistance in the development of the concept "ideology of the modern military of Russia" was provided by the $f$ Walter Benjamin's work "On the concept of history". The German thinker believed that in historical event, there are voids, unfinished project of leaders and participants, i.e., because the event remains incomplete in its past, this leads to the repetition of that event once again. However, the story gets back not as factionist, but in the form of text, sayings, messages, etc., i.e. in ideological format.

\section{Methods and Materials}

Ideology is the universal, the general concept that organizes the discourse. For example, the concepts of "democracy" or "communism" are clamps or ties of all other signifiers, which are valid in this co-society:: if you say democracy, in the economy this means the extraction of surplus value, in the organization of power - elections, in politics - about womenfeminism, in relation to the nature - environmental movement and so on, if you say communism, in politics it is the dictatorship of the proletariat, in relation with women - the right to work, equal with men, in relationships with nature - the work on phase, etc. The core ideology or "weighted," meaning exists for organization of discourses with the aim to stop free flying of signifiers.

In Marxist ideology both, "fair" or naive consciousness are the legacy of the Enlightenment. In Marxist ideology, the one who was its carrier, sincerely believed that communism is the future of mankind - from Karl Marx to Louis Althusser and Jean-Luc Nancy.

For example, assessing the political processes of the 30-ies of XX century in Russia the researchers have noted the coincidence of personal truth and the good of the revolution (Zizek, 2008). Bukharin believed in the idea of revolution, considered himself a Communist, but that's why when he was offered a deal: to incriminate himself for the revolution, he muttered on the court the recognition in espionage. Modern liberal ideology does not pose the question of truth, of honor or duty someone confesses one or another ideology. Moreover, liberalite is such consciousness, which is characterized by a certain fault, fissure, non-recognition of himself and non-recognition ... of something in itself, namely belonging to ... ideology. The question is not to see events and things as they exist by themselves, without the "curve" mirror ideology, but in understanding why joint Genesis needs in ideological processing.

The place of sincere subject of ideology took the cynical subject. In modern societies, whether democratic or totalitarian cynicism is part of the accepted rules of the game. The dominant ideology does not imply a literal attitude. It is possible that of the greatest danger are those who literally follows the ideology that is expressed in such sentiments as Islamic fanaticism, obsession. In the destruction of the shrines of Christianity they act consistently, because the prohibition of the image is included in the Islamic Canon. A new subject of ideology is cynical subject. Characteristic of cynical subject is not the belonging to a certain things, not the expression of any substance belonging to a nation as an "ethnographic things, but the exchange of messages not related to the referent. The President as an entity is the guarantor of the joint being of the people, nation, and as a subject of ironic message - the source of peacekeeping wars.

The words broke away from things. R. Bart, describing the modern era, argued that the real is a myth, and expression, display of things that are not existing, is solely a communication system.

Louis Althusser, speaking about ideology, wrote that it was struggling for Words. As the reality of the class struggle presents ideas that are represented by words, ideology is a representation of representation. Words are explosives, tranquilizers, poisons (Althusser, 1976; \& Barthes, 1989). Modern political philosopher Slavoy Zizek, determining the cynical subject of ideology articulates his position in a speech this way: you know that I tell a lie, I know this too, but nevertheless, I say it. (Zizek, 1989).

Ideology has ceased to be what Marx called false consciousness, it is possible to expose, de-constract, subjected to reduction, to expose in such way, that no one will take it into consideration. Exposing of the lie - Marxist or bourgeois, created career of politicians, journalists or hurled them because the word refers to things, they meant something. When ideology has become the Kingdom of "empty words", a cynical place of the subject? There is no simple answer. I will only note that the meeting of the first Congress of people's deputies of the USSR is fully aired on TV, it was decided by the delegates. I remember this immersion in cleansing atmosphere of liberation from totalitarianism, we were captured. 
Appreciating the fact whether it was the mimesis true or false, will give a historical distance, the distance. The participant in this Congress Roy Medvedev today recognizes that each speaker spoke in front of the whole country, many were not ready to speak at this Congress. (Medvedev, www.gorbi.ru/userfiles/20_let_pervogo_sezda_narodnyh_deputatov, 2009). It means there was conscience, responsibility, understanding of the scope of the event.

Due to the cynical subject it is impossible to keep it simple metaphors - picking of masks, flushing of the skin. Peter Sloterdayk in the "Critique of cynical reason" argues that the dominant contemporary ideology became cynical modus. They know perfectly well what they are doing, but nevertheless continue to do so" (Sloterdayk, 1988). A cynical mind is no more naive, it paradoxically is enlightened by "false" consciousness: conscious understanding of falsehood, fully aware that for ideological universals hidden private interests, he's not going to abandon these universals freedom, human rights, equality is used as a tool of coercion to consistency "With the war in Iraq, Libya is evident America's desire to control the country's rich oil and ideological cover is to protect the rights of people to life in a democratic state".

Today, even the creators of ideologies do not assume that it will be taken seriously, it had manipulatively completely external and instrumental status. However, things became more complicated : really, on what is betting ideology is to act as upright as possible, more formal. The more coarser is the lie, the better it is recognized as such within the main goal, but reaches the result through the bypass path. The ideological effect is a byproduct of the goal. For example, through the Internet is send a message about the purpose of the level of pensions by gender principle, the intention to calculate the rate depending on the number of years lived after retirement, and because women live longer, they and the pension amount should be set lower. The Internet community expresses bewilderment, indignation, etc., but in general, the ideological effect should be considered the preparedness of public opinion to change of pension legislation that something can be reviewed, but not to that extent...".. On the main message is placed a ban, but a side effect is with agreement to consistency, further Genesis..., is legitimised, the authority may continue to rely on compromise. One could argue that this message is not related to the sphere of ideology, but rather deals with the specific policies of the government in times of crisis. It is important on a simple example to analyze the reception: displacement of goals and returning the parts of replaced in the form of after-effect. Another example is to give militiamen of Donbas the ability to protect their home, family, mine. A side effect was the growth of anti-Kiev moods, whereas in the beginning of the conflict their Russianness, their specific in the attitude of Ukrainians understand a small number of the population DND.

An ideological effect through the "workaround" contributes the replace of "hard" meaning that uniquely prestigieuses to his other meaning (anti-communism, anti-Americanism and others) on "floating" meaning of democracy, freedom, reliance on the law and other quite mantric spells of modernity. Metaphorical redundancy of ideology is based on "floating signifiers, when none of the parties, their uses, does not possess the "true meaning", hence the phrase "genuine democracy", "formal democracy" and other. However, the "floating signifiers" is needed to keep in communication field, because, although no single actor can show them the truth still remains the same articulation. The West, the USA, Russia and others talk about rights, the rule of law, democracy and so on, that allows to draw on a shared horizon of meaning. In a floating signifier is included not description of hegemony, but the description of dialogue. "We are for peace" is a General descriptive value without regard to the fact that each of the speakers means world peace-war, pacifism, or Jihad. Hence, two options are possible-the offset into the private sphere of values, for example, in my opinion: peace is the absence of a major war or an endless exchange of discourses - the opinion of the President, foreign Minister, defense Minister, deputies, etc., in order to clarify concepts. In the modern world the essence of educational and hermeneutic competence is immensely increasing (Kononova \& Yakimova, 2013).

Authentic singleness is a community of singularities, a community without a common, individual beyond freedom and determination, in Russian, self-will (Deleuze \& Guattari, 2004). In this case, the individual shows himself as an example, a case in which, as is well known, and therefore is the case because is unique, inimitable, this is just the sample itself. Giorgio Agamben, contemporary Catholic philosopher, defines the future of the community as habitat idle samples of themselves (Agamben, 1993). If we correctly understood, we will try to explain on the example of cartoons of the prophet Mohammed, published in the magazine "Sharlee...". An unbiased view leads to the conclusion: cartoons are of obscene content and primitive form, we have had many complaints to their artistic taste. But cartoonist loves not the contents but caricature as the sample itself. Not for the sake of criticism of something in Islam, not in order to think about split French community, he does it for self-expression, cartoonist loves himself... in the cartoon. For the sake of manners of himself, as an idle pattern itself, without purpose, and meaning for the sake of supporting their own narcissistic illusions he places himself in the place of universal liberty, rights, but this is a place that he can't take. The phenomenon of this unnecessary, not needed, idle, inactive essence of being is the event of the society without relying on universal: be on your own style to be and nothing more, this is the task that puts ethics abolition of the universal, in the end, the expense of ignorance and cynicism. To glide from one way of being to another is to move from idiocy to another: provocation, similar to the "Sharlee" -Paris in a month was repeated in Copenhagen. If Sartov's existence was sovereign, had a 
support freedom and responsibility, and Heideger's critique of das Man warned existence from falling into anonymity is non-parted "being-with-others", in modern society singularities both strategies were defeated: no mass, but no personality. The singularity is lost in the estimation of reality, for it remains as a system of signs of Other (government, media, authority), which as Another terrorist ( insisting on his own way to be exclusively their own way, for every singularity is Another figure of violence) should be eliminated. Moderate, balanced view results in the following: generally human compatibility is arranged so that one remains "average" presence, neutralized, "being-with-others." The devaluation of Genesis as the only is inevitable, that does not preclude the fight for the truth with compatibility (Kirsanova \& Korotina, 2014).

In the case of reliance on a single specific statements we sometimes face the threat of loss of universals, one of which is the ideology. The absence may not quite true, often of irrational "categorical imperative" in the form of ideology provides the minimum homeostasis society and man. Moral obligation in the form of the Kantian categorical imperative: act as it should, because debt is debt, debt is above all, the ideology replaces the Aristotelian measure, a compromise between mimesis and logos. Ideology allows mimesis in the form of recklessness: to act, not recognizing the inevitable, to act against the need to refuse races-to read, to weigh the "pros" and "cons", the common name of this is obsession. But you can also use the properties of the logos, to retreat due to unavoidable to take into account the strength of the enemy, to respect the enemy, not to indulge in total hysteria, let's call it courage logos.

What forms, in addition to ideology, does Genesis possess? According to J.-L. Nancy, at the beginning of human history a great place in the Constitution of communism occupied Greek theatre. Social is putted forward being (Nancy, 2000). Spectacular social presents not knowledge of something (gnosis), but himself as scenographic practice presents in fact, in the body. The idea of "we" is not a representational thought (idea, concept), but praxis and ethos. (Nancy, 2000). The difference of social and ideological consists not in the absence of staginess, necessary to put compatibility, they are identical in it, but in that mass social neglects the logos. If the determination of the location of the logos in ideology is significant, what kind of logo are we talking about, about consciousness, thinking, reflection as the properties of the individual or of the Logos in the form common to all practices - circuses, sporting events, public executions, trials, military parades, taking the oath, the oath of the President, etc. From the point of view of a French Marxist Louis Althusser, ideology is a way of identifying stakeholders, aiming to take their assigned positions in the social formation. Ideology exists only in ritualized practices, which, in turn, exist within the apparatus. (Althusser, 1976). Ideological apparatuses exist in the form of social institutions such as family, media, Church, education, political parties, trade unions, the entertainment industry. During the Paris spring 1968 J.-P. Sartre argued that "structures do not come out into the streets", giving priority to human existence. The revolution was defeated, sovereign existence did not become a pillar of the new joint existence, based on freedom. The essence of the disagreement of Sartre and Althusser was to prioritize between existential philosophy and social philosophy. Social, according to Althusser is the structure or format, as we would say today, and the position of the individual is the flicker of existence inside the structure. Flickering means that the subject is going in the way or is issued as a figure of speech, regardless of desire or effort of a particular person, only an imaginary or real migration, drift inside the structure ( $\mathrm{I}$ - a Communist, and Communists - special people, and not Vice versa: I'm a good person, and - Communist). I am referring to the film Y. Raysman "Communist" (1957), which presents suggestive ideological image with a predominance of mimesis above logos. To get in the format of discussions, interviews, role, etc. does not imply the existence of their own way, rather, it is the opportunity to become a message for Another, and therefore for himself. Interpellation is the ability to call, "the Lord, "Abraham !" - "Here I am" means that the entity already exists in the mode of understanding (faith of Abraham is absolute), own speech only grows to values that are already formed by structure. The subject gains a voice that called drop words in "being-together", and thereby loses its transparency of Genesis as their own, "says not what he wants". And who is the customer of that, "what" says in addition to the subject? Ideology, being completely external to the subject, even absurd machine cast to speech based on the automaticity meaning that the individual subject is not able to overcome. In the assessment of their present living in Russia can be carefully noted that the discourse of liberation of consciousness from "totalitarianism" has not been universal. Ideologies tend to have a certain structure and functioning, which makes it a non-historical reality, that is all historical. These functions of ideology are immutable and cash, i.e. universals. Logos of ideology can be subjected to procedures of rationality: a query about the Genesis, rationale, evidence, verification, etc., that is, the mastery of what Marx called the weapon of criticism. Proof of the truth of" ideology convince the mind, while its suggestion is based on the imitation of samples, adherence to custom and tradition, the experience of the archetypes and the collective unconscious, etc.

Are there images, of fatally suggestion? Eternal samples do not happen, but in ancient times and currently ideology can be found its justification in nature and history. The nature of things - the environment, the landscape also has signs of suggestion. Nature creates the myths about mythology forests, steppes reasoned Russian historians and 
philosophers Karamzin, Klyuchevskiy, Kostomarov, Berdyaev, the Russian film industry has also actively appropriated "nature" as an actor, brought it as a character in the picture (Dovzhenko's "Earth", Tarkovsky's "Andrei Rublev", Zvyagintsev's "Leviathan" and others). However, the elements of the forest, desert, sea, mountains have no signs of something prepared, they in a literal sense is natural, and there is a kind of maturity in a prepared things, thus causes and effects are causal in nature: we have made our history, this is our history (Heidegger, 1996). Thus rather vague meaning of the concept "nature" cannot be used as an ideology with absolute precision, although in the mythpoesis it can be applied as an ideological sign. (For example, nature is" fragile ice lake" is a helper for Russian soldiers and is an enemy of the Teutons in the film S. Eisenstein's "Alexander Nevsky). However, it can be argued that in order to be used as an ideological symbol, the concept of "nature" must be substantially transformed, thus made in the history of the people, the nation learned from fyuzis.

Why history often becomes a hostage to ideology, why it has been managed by different actors who have the opposite goal (Prince Vladimir is an iconic figure for both Russians and Ukrainians, but it performs a different ideological function). The history contains in itself the ontological contradiction: on the one hand, it is a kind of continuous duration of events (the story never stops), and on the other - co-beingness (this is historical fact, which is given a meaning (Barthes, 1970). Duration as an objective list of facts, as chronology has for a long time been an object of interest of historians, for example, guided by the need to have reliable information Thucydides paid informants of both sides as the Persians and the Greeks. Greco-Persian war lasted for about 40 years, evidence about whether it was a victory or defeat, each party would interpret differently (Barthes, 1970). Tyrants or politicians are interested not in history, but in originality, moreover, each historical age writes the history at own discretion (Ankersmit, 1988). The Russians wrote the history of the great Patriotic war as winners, and the Germans as a defeated and guilty of the genocide of the peoples. The historical epoch is changing, there is a new balance of political forces: Germany today is the most developed and richest country in Europe that supports the desire to rewrite history again "In particular, to present to Russia the violence inflicted on German women by Russian" (J. Habermas). The question whether it had happened in really is a problem for historians. The ideology is that in place of the thesis "devil take the hindmost" takes place the substitution of the idea of historical justice. Germany wants to rewrite the story from the point of view of the winner. Accusations of trying to "rewrite history again" are heard from both Russia and Germany "It is adjoined by the Baltic States, Ukraine, Poland and others". Obviously, this involvement is political and ideological. It's a debate of ideologies, not historians.

Let's try to isolate the empirical perceptions, which today have circulation in the Russian consciousness: statehood, nationhood, patriotism, the compilation of a list of victories - from Alexander Nevsky to the heroes of space - Gagarin and other. The complexity of the problem consists in the choice of facts and historical figures: the ideology can not rely on ambiguous assessments, so it is forced to simplify the historical Genesis, present it in the form of uniqueness, in order to achieve predictable reaction of the recipient. On what really ideology makes a bet is to act as upright as possible: pull facts from historical context and to give them a certain interpretation. C. Benjmin, having the experience of living in the atmosphere of Nazi propaganda, wrote the following: "the will to power in the interpretation is the right of the winner from his point of view to write history" (Benjmin, 1939). Empty homogeneous time of history (historical continuum time) becomes filled, constantly interrupting event. In the historical co-existence remain voids, because the ideology watchman rejects that what refers to the history itself, prevents attempts to grasp the meaning of factionist as such. The objectivity of historical hermeneutics decreases in process of time approaching to the present moment. History has value for ideology because it allows to build "an empirical muscles": to cut pictures for ideological format. The cause of the ideologization of the history is abuse of the "will to interpretation", but it is only its subjective causality.

The objective reason of the possible misunderstanding is that when the event occurs "The collapse of the USSR", the agents are not able to understand its true meaning, its traumatic pattern is recognized only when it is repeated. The first split is a traumatic accident, repeating of events (leaving of Ukraine to Europe) constitutes the inevitability of the break. Possible unions of Russia and Ukraine in the future are not excluded, but are different than the USSR. Hermeneutic interpretation never gets to the point of present: either the subject put off the interpretation, delays the judgment (the incident has happened, and the events not yet), or the subject of their reasoning runs forward such haste make a person prone to hysteria in politics, ideology, history. When becomes the "right" moment of interpretation "The transformation of causality in the eventfulness" it will be difficult to determine, this is the art of politics. It can be referred to the political sensitivity of Lenin in the definition of "the right moment" of the October revolution "October night of the year 1917", while Stalin made a mistake in assessing the time of the beginning of the great Patriotic war.

\section{Concluding Remarks}

It is permissible to include following in the objective nature of the ideologization of history: there are events in the past, 
which has not been completed, they had to be different and not such as they remained in their incompleteness. It is known that "the Versailles peace" secured vengeful stance of winners over Germany, has defined it place, not in accordance with its disposition as middle European countries "Germanyis Central Europe, and it took the place of the outcast", that gave rise to the German revenge in 30-40 years of the XX century. Unfinished eventfulness encourages subjects to return to the previous history: only this intervention can make the past the way it always was. The humiliation of the Russians in the 90-ies, depressive social background, barely covered by hysteria of Westerners, in the form of compensatory restoration prompted us to catch "the return of the Crimea". "The body loses organs", the folk essentialism suffers damage that causes the desire of historical actors to restore everything as it was". Historic injustice, resentment make the past an easy prey to the ideology.

The repetition of the past, the return of the "expelled" is due to the synchronism of the present and the past (the ideology in this case only performs the role of an agent), the result of this process transforms the co-existence of a closed monad, in total ideology (Domanska, 1998).

\section{References}

Agamben, G. (1993). The Coming Community. University of Minnesota Press, pp. 105.

Althusser, L. (1976). Ideology And Ideological State Apparatuses, Verso, London• New York, pp. 273.

Ankersmit, F. (1988). Narrativie Logic: A semantic analysis of the historian's language. The Hagus: Nijhoff, pp. 56-72.

Barthes, R. (1989). Collected works: semiotics, poetics. Progress.

Barthes, R. (1970). The discours of Historyl/ Structuralism: A Reader ed., and introd. Michael Lane.

Benjmin, W. (1939). Uber den Begriff , Geschichte.

Deleuze, G. and Guattari F. 2004. Anti-Oedipus of Capitalism and Schizophrenia. London and New York: Continuum, pp. 432.

Domanska, E. (1998). Encounters: philosophy of history after postmodernism. University of Virginia Press/ ISBN - 10:0813917670.

Habermas, J. (2006). The Pivided West. ISBN 9780745635194.

Heidegger, M. 1996. Being and Time. Albany: State University of York Press.

Kirsanova, L. \& Korotina, O. (2014). On the contents of the protest conscience in Russia. Wolrd Applied Sciences Journal 31(5)

Kononova, O. \& Yakimova Z. (2013). Competence as an object for Assessmen and Measuremen in Training Quality Control System//World Applied Sciences journale. T.27. pp. 536-540.

Medvedev, R. (2009). First congress USSR people's deputies: 20 years later. www.gorbi.ru/userfiles/20_let_pervogo_sezda_ narodnyh_deputatov.

Nancy, J-L. (2000). Being Singular Plural. Stanford : Stanford University Press.

Sloterdijk, P. (1988). Critigue of Cynical Reason. University of Minnesota Press, ISBN 0-8166-1586-1

White, H. (1973). Metahistori. The Historical imagination in Nineteeth-Centri Europe. Baltimor and London: Johus Hopkins University Press.

Zizek, S. (1989). Sublime Object of Ideology.VERGO, London, ISBN 5-901116-01-1.

Zizek, S. (2008). The Fragil Absolute: Or, Why is the Christian legacy Worth Fignig For. London: Verso. 